\title{
Assessment of incubators capacity building on agribusiness in Sudan
}

\author{
Mary Njeri Thiong'o* and Sunday Baba \\ International Institute of Tropical Agriculture (IITA), Oyo State, Ibadan Nigeria. \\ *Corresponding author. Email: mariathiongo@yahoo.com
}

Copyright (C) 2019 Thiong'o and Baba. This article remains permanently open access under the terms of the Creative Commons Attribution License 4.0, which permits unrestricted use, distribution, and reproduction in any medium, provided the original work is properly cited.

Received 12th November, 2019; Accepted 16th December, 2019

\begin{abstract}
The purpose of this paper was to assess the impact of incubation on growth of agribusiness in Africa. The target population for this paper was incubators based in Sudan. The research comprised of 160 youth incubators (from four States). Data was collected using structured questionnaires and interviews from the selected respondents. The finding showed that all the incubations reviewed had good facilities to conduct training. Most of the training offered by incubations were to increase the productivities and very few trainings on promotion of the business. These findings revealed that incubators in Sudan lacked critical knowledge to fully develop agribusiness owned by the youths into high profitable business. The findings confirmed that agribusiness incubators in Sudan ranked very low on business case skills, collaboration and partnership, analytical and problem-solving skills, financial fundamentals, team work and sales skills which are the core aspects of business growth. This study concludes that the significance of the business incubation on growth of youth agribusiness enterprises is directly proportion to capacity of the incubators. Based on the findings, there is need for incubators in Africa across all sectors to build their capacity to become effective in supporting startups.
\end{abstract}

Keywords: Agribusiness, business incubation, knowledge skills Sudan.

\section{INTRODUCTION}

Youth unemployment around the globe has become a major challenge in the 21st Century. According to the World Youth Report (WYR) (2010), approximately 88 million youth around the world are unemployed and underemployed. In Africa, the Sub-Sahara is one of the regions highly affected by youth unemployment. Nearly 75 million young people are unemployed globally and this is an increase of over 4 million since 2007 (Isabelle, 2013). United Nations (2015b) noted that there were 1.2 billion youth aged between 15 to 35 years globally and among the greatest challenges facing many countries today are inadequate human capital investments and high unemployment rates among youth (Mirkin, 2010).

Business incubation provides entrepreneurs with an enabling environment in the start-up stage, helps reduce the costs associated with launching an enterprise, increases the confidence of the entrepreneur and helps link them to the resources and networks required to scale their enterprise. Al-Mubaraki et al. (2014) argued that the main goal of a business incubator is to encourage the development of new business within the local community. This increases the number of available jobs in the area thereby creating additional revenue to the countries. With the increasing levels of youth unemployment, there is a need to find out whether the increasing business incubators have a significant effect on reducing these figures.

Business incubation is reputed to have a high success rate in terms of guarantees of business survival. However, according to Drouillard et al. (2014), only $40 \%$ of the incubated start-ups are able to become fully independent after the incubation period which runs for a period agreed between the two involved parties. It is also important to note that out of the successful $40 \%, 8$ out of 10 are 
technology start-ups. This is a contrast to other findings that have tended to show high success rates for incubated businesses irrespective of the sectors (Gichuri, 2018). There are various types of business incubators including virtual incubators, incubators without walls and incubators with walls. However, despite the establishment and diversity in models established, there are disparities in service provision and consequently, the perception of recipients of incubation services is that they fall short of their expectations (Kibuchi, 2016).

However, it is further documented in other studies that $85 \%$ of incubator-launched businesses succeed (UNDP, 2012). In another twist, Fetsch (2015) in her review of 38 studies on incubation notes that incubators might not prove more effective at creating successful businesses than un-incubated businesses. In most of the reviewed studies the focus has mainly been on services provided by the incubators and not much focus on neither the effectiveness of the services, the entrepreneurial orientation of the entrepreneurs and business owners patronizing the services of the incubator nor job creation (Mishigragchaa, 2017).

The United Kingdom and the United States focuses on the creation of science-based companies that collaborate with research institutions (e.g., universities) that would be considered more as science parks (Al-Mubaraki et al., 2013). There are currently 205 incubators active in the United Kingdom. The incubators provide businesses with office/work space, provision of training for entrepreneurs, access to networks and financial support to start-ups. These incubators aim to support young firms through the early and fragile stages of growth, helping them avoid the mistakes of others, saving time and money and increasing survival rates (Bone et al., 2017).

In the case of China, for example, the extensive business incubator program developed in the early 1990s has played a key role in facilitating the country's transition from a socialist to a market economy by enabling the commercialization of technological developments and promoting a culture of innovation across China.

In Africa, many governments and private players have taken action to address this widespread challenge. One approach gaining more traction is the establishment of business incubators, which can help speed up the growth and success of early- stage companies. These hubs help bring together angel investors, state governments, economic-development coalitions and other investors (Ayatse et al., 2017). Incubators serve as an accessible platform for bringing together technologists, investors, tech companies and hackers in the area. Each incubator shares a focus on young entrepreneurs, web and mobile programmers, and designers (Ogutu and Kihonge, 2016).

South Africa's has over 20 incubators supporting entrepreneurs in sectors as diverse as horticulture, construction, chemicals, ICT, biotechnology, metal fabrication, furniture manufacturing and platinum beneficiation. While there are a few private sector-led incubators, most are supported by the national government and to a lesser extent by provincial and local governments. The South African Business and Technology Incubator Association (SABTIA) were formed by incubator professionals and has since become an organization representing incubators in southern Africa (Ogutu and Kihonge, 2016).

Muzinda Hub, launched in 2013 is the largest technology hub in Zimbabwe. In 2015, more than 700 students graduated from their program. Driven and inspired by Econet Wireless Zimbabwe, the hub has nurtured thousands of students through its Technology and Business Incubation Program. Muzinda Hub won numerous awards for their outstanding contribution to developing the next generation of Zimbabwean tech gurus. Muzinda Hub gives opportunities to their program graduates by consulting for private businesses (Bone et al., 2017).

The Botswana Innovation Hub $(\mathrm{BIH})$ was incorporated to develop and operate a science and technology park to aid in diversifying the economy and help transform Botswana into a knowledge economy. BIH promotes research, development, education and innovation; supports startups and existing companies; and attracts companies, universities, research institutes and advanced training institutes. The hub's focus sectors include ICT, mining technology, biotechnology, energy and environment (Ayatse et al., 2017).

Anza is a business incubator in Moshi, Tanzania that provides a range of services to start, support, and scale local social impact businesses. Anza exists to catalyze economic empowerment and community benefit in Tanzania's Kilimanjaro region by partnering with aspiring entrepreneurs to incubate and accelerate social enterprises. Anza's mission is to bring together highquality, technical support from the UK, Canada, and Tanzania to create a high-impact social enterprise incubator (Pettersen et al., 2015). While Africa is taking notable efforts to support its burgeoning business environment, it is worth noting that most African incubators focus on leveraging resources for tech entrepreneurs. Without resources for aspiring entrepreneurs outside the tech sector, there is a large gap that future business incubators will need to address in order to allow more small businesses to launch, survive and grow to support Africa's development (Mian et al., 2016).

Therefore, the main purpose of the survey was to address the following objectives:

1. To assess training conducted to equip the youth with agribusiness skills.

2. To assess the level of agribusiness knowledge and skills available to management of incubation.

3. To assess skills and knowledge needed to promote the work of agribusiness incubation.

4. To assess opportunities to promote the knowledge and skills in agribusiness. 


\section{LITERATURE REVIEW}

\section{Theoretical framework}

Multi-Objective Incubatee Selection Model was proposed by Wulung et al. (2014) and it combines the potential incubatee's technical strengths as judged by various aspects of its business plan and the individual entrepreneur's characteristics within given constraint parameters to assist incubator managers make a decision on the most suitable incubatees. In the model, incubator managers are the decision makers and start-ups or young MSEs are incubatee candidates.

The model considers multi-objective functions consisting of profitability maximization, incubatee survivability, and worker absorption maximization to reduce unemployment. Incubatee candidate properties, such as technology level, profitability, survivability, worker absorption and total assets are the inputs, while incubator capacity, maximum total assets, minimum technology level and industry priority proportion are the constraint parameters. Applying the proposed model consists of several steps: First, candidates propose their business plans to the incubator manager; second, the incubator manager assesses the technology level of the incubates and the personal attributes of the entrepreneurs; and third, the applicants are screened for maximum total assets and minimum technology level to eliminate inappropriate candidates (Wulung et al. (2014).

\section{Empirical studies}

Guceri-Ucar and Koch (2013) carried out a study on business incubation practices and software start-up success in Turkey. The researchers derive the following propositions regarding how business incubator practices may contribute to tenant success: first is that location of the incubator will contribute to tenant success if it is in close proximity to an institution conducting innovative research in a similar area, if it provides locational advantage in terms of access to target customers, or if it provides ease of access to qualified employees. Second is that an open office structure will contribute to tenant success by enabling networking among tenants and creating opportunities for strategic partnerships. Third is that quality of the work environment provided by the incubator will enhance tenants' efficiency in product development, and contribute to human capital by increasing employee motivation.

Peters et al. (2004) results showed a significant difference in the number of companies graduating among the three types of incubators with different governance structures, namely non-profit, for-profit and universitybased incubators. Grandi and Grimaldi (2003) put forward two research hypotheses: (a) that the intention of the founding teams to set up relations with external agents is influenced by the degree of articulation of roles and the completeness of the founding teams; (b) that the founding teams' frequency of interaction with external agents is influenced by the frequency of interaction with external agents of the research groups of origin and by their scientific and technological excellence. The degree of completeness of the founding team negatively affects the dependent variable, thus confirming that one of the main drivers behind the intention to set up external linkages is represented by the search for resources not available internally.

Soetanto and Jack (2013) argued that networks at incubators can be seen in two dimensions. In the first dimension, they define incubator firm networking activities in terms of resource type, i.e. tangible and intangible resources. In the second dimension, they define networks of incubator firms as external and internal. Internal networks refer to the relationship among tenants while external networks refer to the firm's relationship with other institutions such as a university and/or research centre.

The growth of agribusiness like other sectors requires high skills and capacity development. Many authors have researched on the role of capacity development in agribusiness sector and this include Babu et al. (2016) who study focus was on strengthening capacity for agribusiness development and management in SubSaharan Africa. In their findings, they revealed that to effectively build the necessary capacities, the skills built by agribusiness education and training must correspond to the needs of the agribusiness sector. Payumo et al. (2017) on their part focused on transforming Sub-Saharan Africa's agriculture through agribusiness innovation. The study reported that various initiatives are taking place in the region, including agribusiness incubation; capacity building, education, and agribusiness knowledge transfer programs at different levels. Partnerships among stakeholders such as government, international groups and private sectors are also growing to boost and encourage better value chain management for agriculture across the African continent.

A study conducted by Etela and Onoja (2017) on sustaining the impact of capacity development initiatives for African youth in agriculture reported that capacity development interventions should be based on real needs identified through assessment of capacity gaps and needs of youth already engaged in agriculture or those considering entering the sector, and taking into account the heterogeneity of youth and their complex and multifaceted needs. Mabaya et al. (2010) in their study concluded that while significant progress has been made in integrating agribusiness management into university curricula, the current offerings are far from comprehensive. The paper recommended that strategies for developing agribusiness education and training initiatives should be developed so as to bridge the gap between current offering 
and industry needs. A report by Johnson (2014) concluded that agribusiness development in Africa needs to be context-specific, by addressing issues of supply and demand. More agribusiness workers need skills and training to increase the value of products, develop businesses and build the capacity to adapt with change. Capacity development is therefore very critical to the growth of agribusiness sector in Africa.

\section{RESEARCH METHODOLOGY}

The study was conducted in all the five States in Sudan (Khartoum, River Nile, Gazira, Kassala, and Gadaref) where agribusiness incubations are located. The study was conducted in 2018 and surveyed all the 160 youth incubators. The study sampled included 9 key informants from 9 universities, 10 key informants from agricultural extension departments, 5 key informants from agricultural research centers, 10 Agribusiness Incubations of five States and 160 youth incubators (from five States in Sudan).

Data was collected using structured questionnaires and interviews from the selected respondent that included both managers working at the incubators and youths who had enrolled with the incubators. The data collected was analysed using descriptive statistics and presented using tables.

\section{RESULTS AND DISCUSSIONS}

The results show that the majority of the youths that participated in the survey were aged 32 years and below. The sample comprised of half female and half male respondents. The majority $(90.0 \%)$ were university graduate hence they were well versed with information sought by the study. The results further show that majority $(85.6 \%)$ were single while $13.1 \%$ indicated they were married (Table 1).

\section{Assessment of existing capacity among agribusiness}

This section presents the findings on the existing capacity among agribusiness in Sudan. The agribusinesses assessed identified six areas of knowledge and skills necessary to performed the agribusiness. The assessment indicted agribusiness had little background on the identified six areas of skills and knowledge. Specifically, they had little knowledge on financial fundamental and business case skills (Figure 1).

The finding presented in Figure 1 shows that majority of the individual owning agribusiness had limited knowledge and skills across various areas that are critical to their agribusinesses. The findings agreed with Mabaya et al.
Table 1. Frequency distribution of youth according to the demographic characteristics.

\begin{tabular}{lcc}
\hline Parameters & Frequency & Percent \\
\hline Age & & \\
$22-27$ Years & 54 & 33.8 \\
$27-32$ Years & 72 & 45.0 \\
$32-37$ Years & 34 & 21.3 \\
Total & 160 & 100.0 \\
& & \\
Gender & & \\
Male & 80 & 50.0 \\
Female & 80 & 50.0 \\
Total & 160 & 100.0 \\
& & \\
Education & & \\
University & 144 & 90.0 \\
Post graduate & 16 & 10.0 \\
Total & 160 & 100.0 \\
& & \\
Marital status & 137 & 85.6 \\
Single & 21 & 13.1 \\
Married & 2 & 1.3 \\
Divorced & 160 & \\
Total & & \\
\hline
\end{tabular}

(2010) who argued that while significant progress has been made in integrating agribusiness management into university curricula in Africa, the current offerings are far from comprehensive. The finding further support Babu et al. (2016) who posited that creating a dynamic and competitive agribusiness sector in sub-Saharan Africa requires building a wide range of capacities at all levels. Similarly, Yami et al. (2019) concluded that without adequate capacity to effectively engage in several aspects of agricultural innovation, transforming agriculture in subSaharan Africa will be a long, drawn out process. The findings of this paper point to the critical role of capacity buildings on the growth of agribusiness sector and reduction of unemployment among the youths in Africa.

\section{Assessment of capacity building need among agribusinesses in Sudan}

The paper also conducted an assessment of the capacity building needs among the agribusiness owners in Sudan. The agribusiness owners were asked to identify most urgent needed skills to promote their business. The findings show that $98 \%$ of them expressed their urgent training needs on accounting and others seven skills (Figure 2).

The findings show that there exists gaps and capacity needs that require measures to address to unlock the 


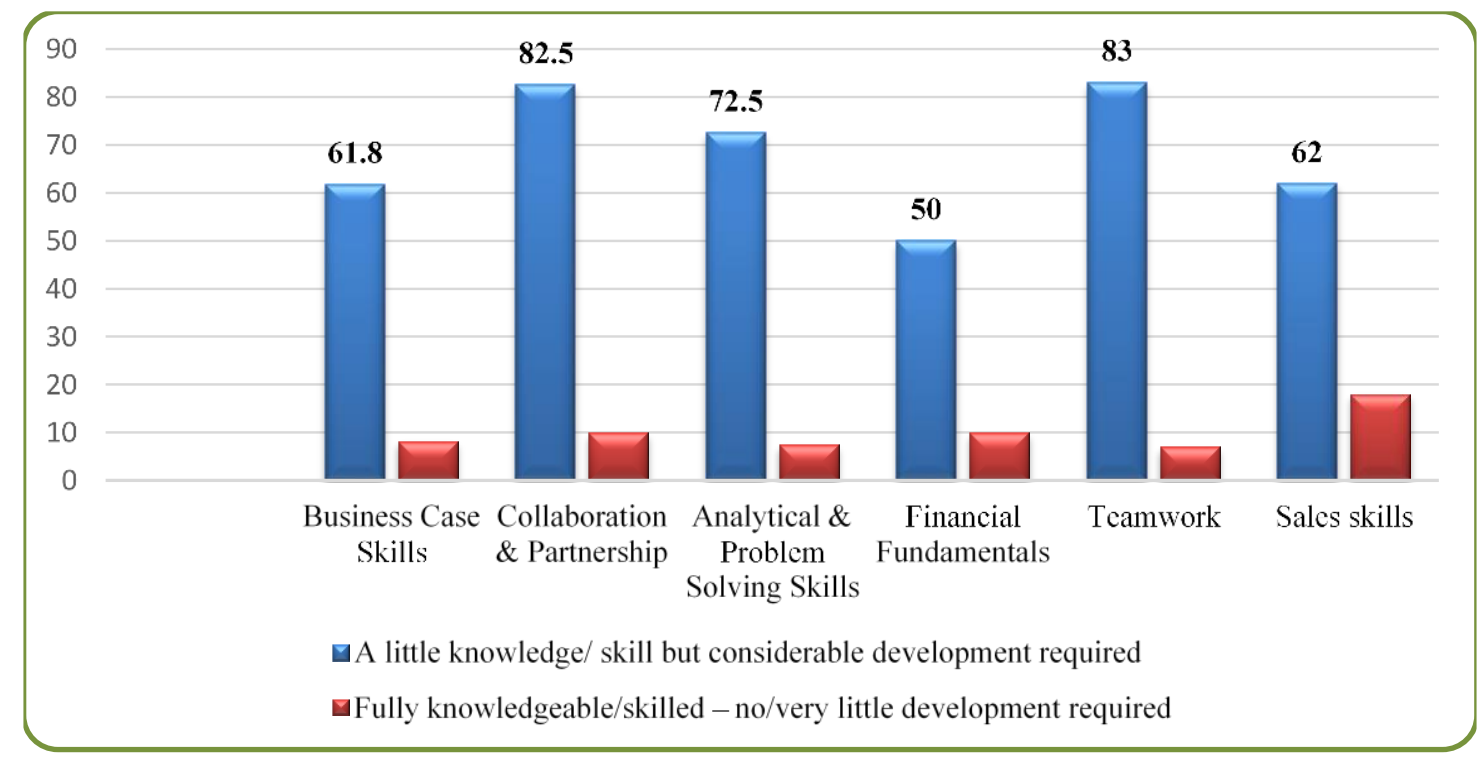

Figure 1. Assessment of existing capacity among agribusiness.

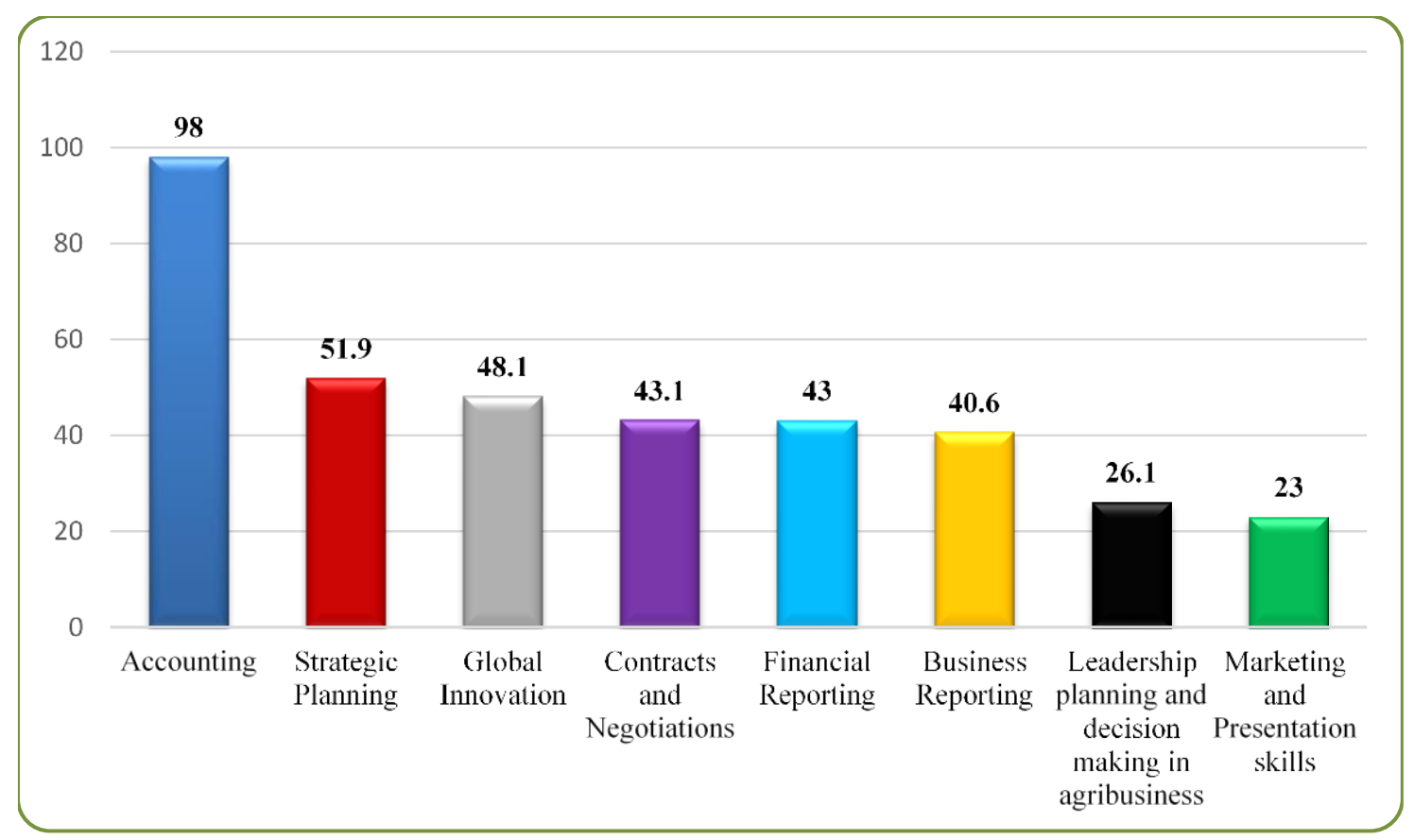

Figure 2. Assessment of capacity building need among agribusinesses in Sudan.

potential of agribusiness sector in Africa. Majority of people who venture into agribusiness lack quality education since those with quality education go for white collar jobs in cities and urban centres. According to Njeru and Gichuru (2014), the young people in the developing countries now prioritize working in offices because they consider agribusiness as a dirty job for people who never went to school. This has led to many young people struggling to get or only access low paying jobs at the expense of engaging in agriculture with the fear of being laughed at. United Nations (2015a) reported that young people represent the largest beneficiaries and victims of the perception that has burdened the agriculture sector. However, this perception may change if the people are 
Table 2. Contents of the training offered by incubation.

\begin{tabular}{llllll}
\hline No. & Content of the training & No. & Content of the training & No. & Content of the training \\
\hline 1 & Seed production & 6 & Marketing & 11 & Vegetable production \\
2 & Seedling & 7 & Report writing & 12 & Natural resources \\
3 & Protecting house & 8 & Accounting and financing & 13 & Nutrition \\
4 & Business & 9 & Protecting houses & 14 & Irrigation \\
5 & Crop production & 10 & Improved seeds & 15 & Business \\
\hline
\end{tabular}

Table 3. Assessment of agribusiness' knowledge and skills available in incubations.

\begin{tabular}{llccc}
\hline No. & Area of knowledge and skills & NL/S & LK/SCDR & FK/SNVLDR \\
\hline 1 & $\begin{array}{l}\text { Knowing how to work and collaborate with others to } \\
\text { accomplish goals and objectives }\end{array}$ & 0 & 80 & 20 \\
2 & $\begin{array}{l}\text { Knowing how to share information and communicate better } \\
\text { throughout the organization }\end{array}$ & 0 & 100 & 0 \\
3 & $\begin{array}{l}\text { Knowing how to develop innovative solutions to solve the root } \\
\text { cause of problems }\end{array}$ & 0 & 100 & 0 \\
4 & $\begin{array}{l}\text { Understanding the costs, profits, margins, and values of } \\
\text { different service lines }\end{array}$ & 20 & 75 & 5 \\
5 & $\begin{array}{l}\text { Encouraging collaboration with others } \\
\text { Understanding how to establish and grow relationships with }\end{array}$ & 0 & 80 & 20 \\
\hline
\end{tabular}

Key: NL/S $=$ knowledge/skill LK/SCDR $=$ A little knowledge/skill but considerable development required; FK/SNVLDR $=$ Fully knowledgeable/skilled - no/very little development required.

equipped with the right skills and knowledge to make agribusiness as lucrative as jobs in other fields. Lack of right skills in agribusiness leads to low production and returns, therefore, capacity development is the only channels to reverse this trend and ensure that agribusiness sector in African countries remain vibrant and contributes significantly in job opportunities creation.

\section{Training conducted to equip the youth with agribusiness skills}

The first objective was to determine the level of agribusiness knowledge and skills available to management of incubation. For all the 160 incubators, the contents of their training were assessed and the results are presented in Table 2. The finding showed that most of the training offered by incubations was to increase the productivities, and very few trainings on promotion of the business. All the incubations reviewed had good facilities to conduct training. All of them had partnership with academic institutions. The finding confirmed that incubators in Sudan were properly equipped to manage businesses owned by the youths to increase their production. The training offered by incubators focused on products mainly, however, other factor critical aspects of business such as distribution, sales and management were least offered. The finding also corroborates with Guceri-Ucar and Koch (2013) who found that quality of the work environment provided by the incubator enhances tenants' efficiency in product development. Lack of focus on other aspects of entrepreneurship justifies the assertion by Fetsch (2015) who argued that incubators might not prove more effective at creating successful businesses than un-incubated businesses.

\section{Assessment of knowledge and skills available for the incubations to perform agribusiness tasks}

The second objective was to conduct assessment of the knowledge and skills available for incubations to perform agribusiness tasks. The results are presented in Table 3 . According to the results coordinators of the incubations, six important areas of knowledge and skills used in the agribusiness tasks were identified. All the six areas of knowledge and skills required more development and understanding. $60 \%$ of incubations lack the knowledge and skills on how to establish relationships with current and prospective customers (Table 3 ). These finding revealed that incubators in Sudan lacked critical knowledge to fully develop agribusiness owned by the youths into high profitable business. The findings are in line with the argument of Fetsch (2015) who argued that 


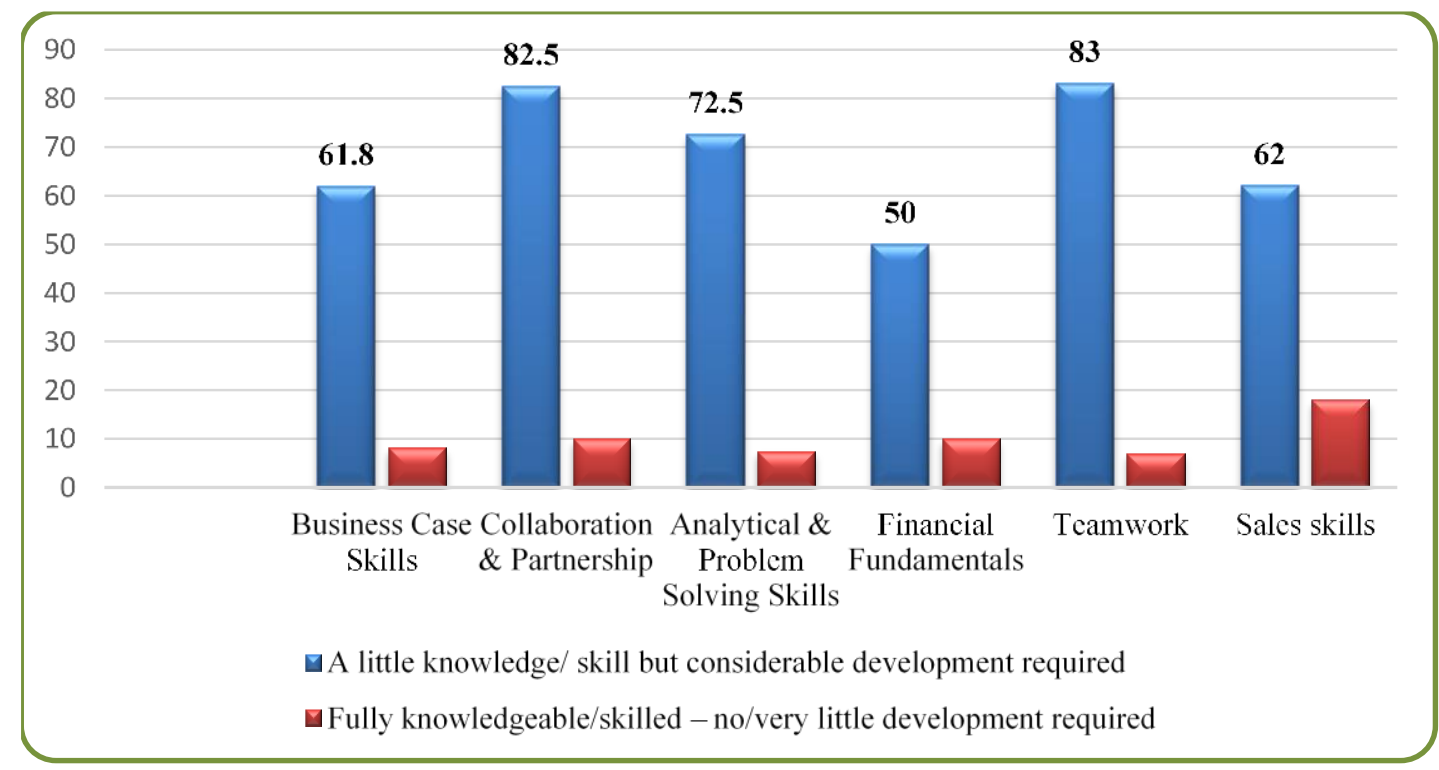

Figure 3. Assessment of agribusiness knowledge and skills among the youth's incubators.

incubators might not prove more effective at creating successful businesses than un-incubated businesses. AlMubaraki et al. (2013) argued that the main goal of a business incubator is to encourage the development of new business within the local community. These roles may not be achieved if the incubators lack capacity in terms of necessary knowledge and skills to equip youths to perform agribusiness roles.

The findings indicted that youths in Sudan had little background on the identified six areas of skills and knowledge. Specifically, they had little knowledge on financial fundamentals and business case skills. These finding implied that majority of the youths in Sudan that engaged in agribusiness activities lack the necessary knowledge and skills to make their agribusinesses profitable and sustainable. The findings concur with Timan and Gangi (2015) who revealed that entrepreneurship education in Sudan is not properly developed since there was only one programme of entrepreneurship education in Sudanese public universities.

According to Mabaya et al. (2014), agribusiness capacity building and training must be addressed for agribusiness to make meaningful contributions and remain relevant in shaping development of the sector. The authors further argued that examining the forces that influence agribusiness is necessary to provide insight into the policies and innovative strategies needed to ensure that this sector better contributes to economic growth and poverty reduction goals.

The findings in Figure 3 further confirmed that agribusiness incubators in Sudan ranked very low on business case skills, collaboration and partnership, analytical and problem-solving skills, financial fundamentals, team work and sales skills which are the core aspects of business growth. Lack of these basic business skills indicate that agribusiness incubators in Sudan lack the capacity support to the growth of youth agribusiness sector. According to Bone et al. (2017), incubators in United Kingdom and the United States provide businesses with office/work space, provision of training for entrepreneurs, access to networks and financial support to start-ups. These incubators aim to support young firms through the early and fragile stages of growth, helping them avoid the mistakes of others, saving time and money and increasing survival rates. Incubators in Africa should also first develop capacity in terms of acquiring talents in entrepreneurship before they can impact positive on the incubated businesses.

\section{Training needs assessment}

The survey further conducted the assessment on the skills needed by incubators to enhance the work of agribusiness incubations. Figure 4 presents skills and knowledge needed to promote the work of agribusiness incubations (identified by coordinators of incubations).

The youth assessed six areas of knowledge and skills necessary to performed the agribusiness. The assessment indicted youth had little background on the identified six areas of skills and knowledge. Specifically, they had little knowledge on accounting, strategic planning, marketing, contracts and negotiation and finally business reporting (Figure 4). These findings indicate that besides increasing production, incubators must focus on financial management and business management aspects to enhance the work of agribusiness incubations. This study 


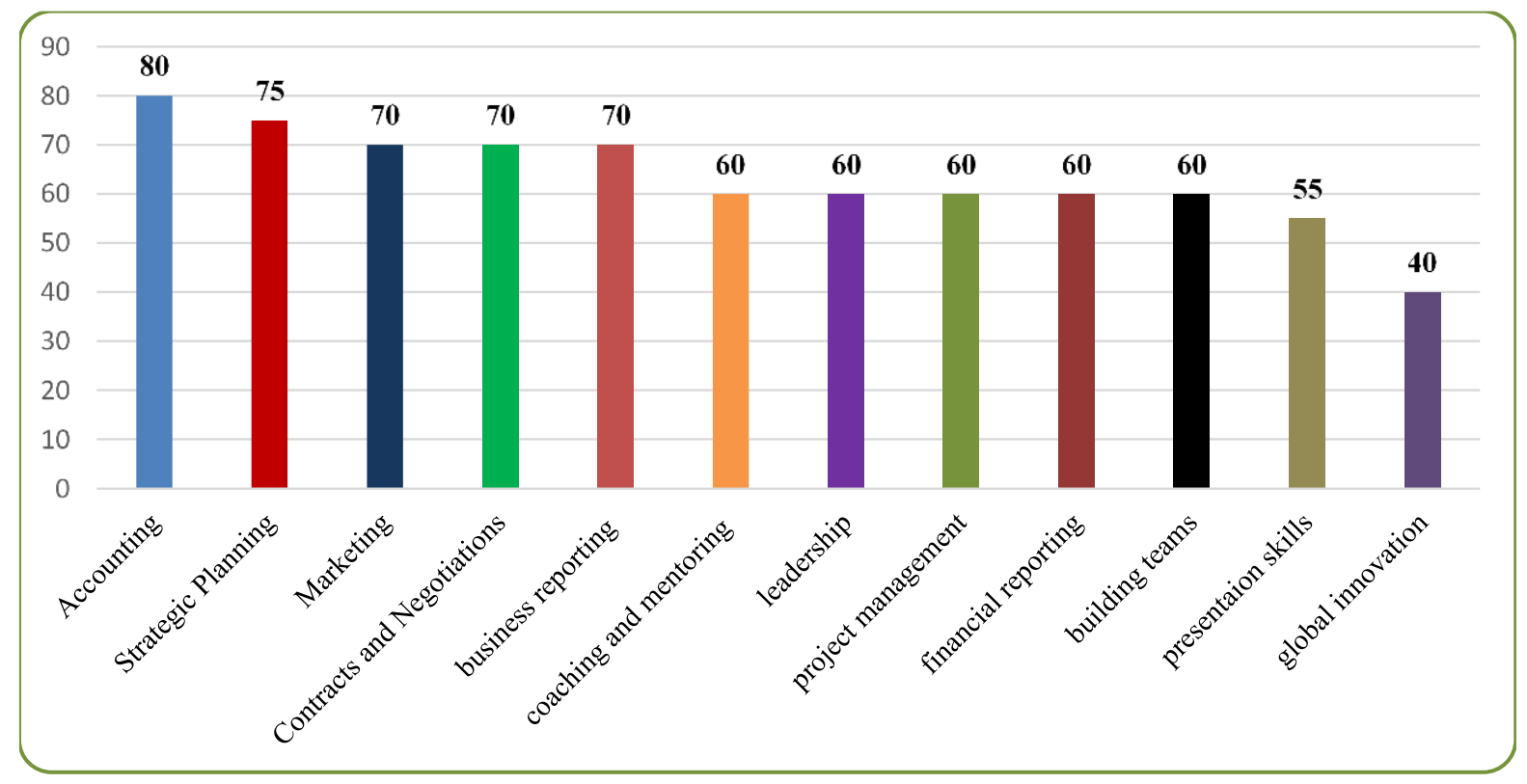

Figure 4. Skills needed by incubators to enhance the work of agribusiness incubations.

supports the argument of Kalidas and Mahendran (2016) that primary role of business incubator is to facilitate the aspiring entrepreneurs by providing them with technical knowhow, easy availability of capital, infrastructure and expertise. Incubator may fail to achieve their core mandate if they lack the necessary knowledge and skills to enhance their work.

\section{Conclusion}

Incubators are with no doubt contributing to the growth of entrepreneurship across the world. However, incubated businesses continue to suffer similar challenges as those encountered by un-incubated businesses contrary to the expectations. In Africa, as demonstrated by the case of incubators in Sudan, this is attributed to lack of capacity by the incubators to perform their role. Lack of basic entrepreneurial knowledge and skills such as business case skills, collaboration and partnership, analytical and problem-solving skills, financial fundamentals, team work and sales skills only point to the fact that incubated businesses will graduate half barked.

This study concludes that the significance of the business incubation on growth of youth agribusiness enterprises is directly proportion to capacity of the incubators. Majority of the Africa based incubators as shown by evidence from Sudan lack capacity to graduate sustainable businesses. The paper further concluded that individual in agribusiness sector in majority of the Africa countries lacked critical skills and knowledge in developing competitive agribusiness enterprises.
Institutions mandated to bridge the skills and knowledge gaps in agribusiness sector lacked the capacity to handle the growing needs. Even though investment in agribusiness especially among the youths has the potential to create employment opportunities, majority of government have given it limited priority. The future of agribusiness sector will remain uncertain is capacity development is not addressed by all the stakeholders.

\section{Recommendations}

Based on the findings in this research, there is need for incubators in Africa, across all sectors to build their capacity. Incubators should increase production of incubated business, invest in equipping the managers of incubated business with other skills such business case skills, collaboration and partnership, analytical and problem-solving skills, financial fundamentals, team work and sales skills. This can be achieved through strategic collaboration, hiring of talents, specialization or training of coordinators to equip them with necessary skills to perform their tasks.

The incubators should ensure that the number of businesses admitted is adequate for their capacity. It is difficult for incubators to be a one stop shop for all entrepreneurship needs for startups, therefore incubators must specialize either in terms of type of business, type of skills and knowledge offered among other specializations. This will ensure that specific incubators perform specific roles hence; it is easy to select incubators depending on their needs. This will enhance the effectiveness of business 
incubation in Africa.

Government institutions and agencies should be involved in regulating incubators. Only those with capacity should be licensed to operate. If left unregulated some incubators will exploit youths seeking business support services financially without offering value for money.

\section{CONFLICT OF INTEREST}

Authors declare that they have no conflict of interest.

\section{REFERENCES}

Al-Mubaraki, H. M., Busler, M., Al-Ajmei, R., \& Aruna, M. (2013). Incubators best practices in developed and developing countries: qualitative approaches. Asian Journal of Empirical Research, 3(7), 895-910.

Al-Mubaraki, H. M., Muhammad, A. H., \& Busler, M. (2014). Innovation and entrepreneurship: Powerful tools for a modern knowledge-based economy. Springer.

Ayatse, F. A., Kwahar, N., \& lyortsuun, A. S. (2017). Business incubation process and firm performance: an empirical review. Journal of Global Entrepreneurship Research, 7(1), 2.

Babu, S. C., Manvatkar, R., \& Kolavalli, S. (2016). Strengthening capacity for agribusiness development and management in Sub-Saharan Africa. Africa Journal of Management, 2(1), 1-30.

Bone, J., Allen, O., \& Haley, C. (2017). Business Incubators and accelerators: the national picture (No. 2017/7). BEIS research paper.

Drouillard, M., Taverner, D., Williamson, C., \& Harris, M. (2014). Digital entrepreneurship in Kenya. London: GSMA.

Etela, I., \& Onoja, A. O. (2017). Incentivizing e-agriculture and agribusiness incubators for youth employment in Nigeria. Nigerian Agricultural Policy Research Journal., 2(1), 42-54.

Fetsch, E. (2015). Are incubators benefcial to emerging businesses? The Kauffman Foundation. Retrieved from http://www.kauffman.org/blogs/growthology/2015/03/areincubators-benefcial-to-emerging-businesses.

Gichuri, O. W. (2018). Factors Promoting Youth Entrepreneurship in Business Incubation Centers. The Case of Kenyan Business Innovation and Incubation Centers (Doctoral dissertation, United States International University-Africa).

Grandi, A., \& Grimaldi, R. (2003). Exploring the networking characteristics of new venture founding teams: A stdy of italian academic spin-off. Small Business Economics, 21(4), 329-341.

Guceri-Ucar, G., \& Koch, S. (2013, June). Business incubation practices and software start-up success in Turkey. In International Conference of Software Business (pp. 178-182). Springer, Berlin, Heidelberg.

Isabelle, D. (2013). Key factors affecting a technology entrepreneur's choice of incubator or accelerator. Technology Innovation Management Review, 16-22.

Johnson, K. K. L. (2014). Innovating the city: challenges and opportunities in establishing incubators and districts in Paris and Boston (Doctoral dissertation, Massachusetts Institute of Technology).

Kalidas, K., \& Mahendran, K. (2016). Review paper on business incubation-A way for sustainable entrepreneurship development. International Journal of Business and General Management, 5(4), 25-32.
Kibuchi, J. (2016). Business Incubation Services Offered to Startup Businesses in Kenya. Unpublished MBA thesis, University of Nairobi.

Mabaya, E. T., Christy, R. D., \& Bandama, M. (2010). The current state of agribusiness education and training in Africa (No. 3082016-5115, pp. 1-21).

Mian, S., Lamine, W., \& Fayolle, A. (2016). Technology Business Incubation: An overview of the state of knowledge. Technovation, 50, 1-12.

Mirkin, B. (2010). Population levels, trends and policies in the Arab region: challenges and opportunities. USA: United Nations Development Programme, Regional Bureau for Arab States.

Mishigragchaa, B. (2017). Accelerators as a tool to support startup ventures: Assessing their performance and success factors. Literature Review. Studia i Prace WNEiZ US, (48/1), 9-19.

Njeru, L. K., Gichimu, B. M., Lopokoiyit, M. C., \& Mwangi, J. G. (2015). Influence of Kenyan Youth's Perception towards Agriculture and Necessary Interventions; a Review. Asian Journal of Agricultural Extension, Economics and Sociology, 40-45.

Ogutu, V. O., \& Kihonge, E. (2016). Impact of business incubators on economic growth and entrepreneurship development. International Journal of Science and Research, 5(5), 231-241.

Payumo, J. G., Lemgo, E. A., \& Maredia, K. (2017). Transforming Sub-Saharan Africa's agriculture through agribusiness innovation. Global Journal of Agricultural Innovation, 4, 1-12.

Peters, L., Rice, M., \& Sundararajan, M. (2004). The role of incubators in the entrepreneurial process. The Journal of Technology Transfer, 29(1), 83-91.

Pettersen, I. B., Aarstad, J., Høvig, Ø. S., \& Tobiassen, A. E. (2015). Business incubation and the network resources of start-ups. Journal of Innovation and Entrepreneurship, 5(1), 7.

Soetanto, D. P., \& Jack, S. L. (2013). Business incubators and the networks of technology-based firms. The Journal of Technology Transfer, 38(4), 432-453.

Timan, E., \& Gangi, Y. A. (2015). Entrepreneurship education in Sudan. Journal for International Business and Entrepreneurship Development, 8(3), 231-247.

United Nations (2015a). World Youth Report. Youth and the 2030 Agenda for Sustainable Development. United Nations.

United Nations (2015b). Youth population trends and sustainable development. Population Facts No. 2015/1. Department of Economic and Social Affairs Population. United Nations. Retrieved from https://www.un.org/en/development/desa/population/publicati ons/pdf/popfacts/PopFacts_2015-1.pdf

United Nations Development Programme (UNDP) (2012). Best practice in business incubation. United Nations, New York and Geneva.

Wulung, R. S., Takahashi, K., \& Morikawa, K. (2014). An interactive multi-objective incubatee selection model incorporating incubator manager orientation. Operational Research, 14(3), 409-438.

Yami, M., van Asten, P., Hauser, M., Schut, M., \& Pali, P. (2019). Participation without negotiating: Influence of stakeholder power imbalances and engagement models on agricultural policy development in Uganda. Rural Sociology, 84(2), 390415. 